\title{
The Effectiveness Of Building Plan Approval. Case Study: Subang Jaya Municipal Council, Selangor
}

\author{
Marlyana Azyyati Marzukhi ${ }^{1 *}$, Azfarnizam Jaafar ${ }^{2}$, Oliver Ling Hoon Leh ${ }^{1}$ \\ ${ }^{1}$ Centre of Studies for Town and Regional Planning, Faculty of Architecture, Planning \& Surveying, Universiti Teknologi \\ MARA, Selangor, Malaysia. \\ ${ }^{2}$ Subang Jaya Municipal Council, Selangor, Malaysia.
}

\begin{abstract}
The growth of construction activities in Malaysia has given rise to the need for more statutory controls to ensure systematic and orderly development. This process of statutory approval refers to obtaining permissions from the relevant authorities to ensure the development follows the standards laid down in the building regulations and certain stages of the construction are inspected by officers from the local authority. This effort is evidenced by the improvement of mechanism delivery system of building plan process, known as One Stop Centre (OSC). In fact, the building plan and construction permit approval come as the most important stage in development as it will determine the exact date for construction to start. However, relatively little is known about the effectiveness of building plan process in the local authority. Therefore, a study has been carried out to investigate the effectiveness of building plan approval process in Subang Jaya Municipal Council (MPSJ). A questionnaires survey has been conducted to forty-seven (47) respondents from the MPSJ's internal technical departments that involved in the process. The respondents have mostly felt that the ineffectiveness of the building plan approval process was due to the incomplete documents submitted to the OSC, lack of knowledge among the Professional Submitting Person (PSP) and the incapability of staffs in handling development applications. Hence, the findings present a synthesis of results for town planners, architects, developers and government agencies to have a better understanding of how the effective and efficient building plan process can rationalize the success of property development sector. Thus, the knowledge serves as a basis for future strategic planning decisions and guidance in the delivery system in Malaysia.
\end{abstract}

\section{Introduction}

In recent decades, the expansion of cities is rapidly happening in the world. By 2030, developing nation's populations will become double in size and the city areas could be tripling [1]. It is also expected that by 2025 the market volume of construction industry could reach $\$ 15$ trillion and is to grow by $70 \%$ or more [2]. The Sustainable Development Goals have given new impetus to improve cities development as stated in Goal 13, to "develop effective, accountable and transparent institutions at all levels" and to "ensure responsive, inclusive, participatory and representative decisionmaking at all levels" [3] This is also in line with Malaysia's transformation agenda to realize the vision to change the government into a more effective and accountable entity

The rising of the population has caused the increasing demand for municipal authorities' services. Such situation seldom happens in the developed nations that faced difficulty to enforce standards, laws, or guidelines in order to deliver efficient and comprehensive services due to the shortages in budgets and resources. Complicated and costly procedures have led many property contractors to build buildings without obtaining complete permit approval. Moreover, if procedures are too complicated or costly, developers tend to proceed with the development without a permit [4]. In fact, it is estimated $60-80 \%$ of building projects in developing economies are undertaken without proper permits and approvals [5].

Therefore, this study is vital to investigate the effectiveness of building plan approval process in ensuring efficient, fast, and competitive approval processes in property development sector, particularly in Subang Jaya Municipal Council.

\section{Figures and tables}

In Malaysia; as same as other nation in the world; acquiring the building plan approval is the important aspects in the development process. If one has started any construction on site while they yet acquired the building plan approval, they are considered to breach the law; be it a new development or just a simple building renovation [6]. No one shall be permitted to start any developments without written consent from the local

\footnotetext{
* Corresponding author: marlyanaazyyati@gmail.com
} 
authority. The written consent is considered as the building plan approval. To ensure that a development complies with all the standards and may be granted all the relevant approvals, one must submit to the local authority all relevant plans and documents. However, the decision-making and consideration process; or procedure; is not stated in any laws or by-laws resulting in the differing ways of decision-making policy by all local authority in the pre-2007 years.

Time and procedures in construction permitting is the biggest "regulatory impediment" to doing business. Time taken by authorities especially for the issuance of design approval is uncertain and difficult to predict [7]. Similarly, a case study carried out by [8] found that the main reason for the delay in refurbishment projects was the process of getting approval from the local authority. When delay occurred, the overall cost for the project would also be affected. McKim et al. [9] mentioned that one of the factors contributing to cost and schedule overruns is the regulatory requirements. In some cases, the drawings had to be submitted more than once due to the amendment that needed to be incorporated. This is sometimes due to the complexity of requirements set by the respective authorities [9].

The success of a development project as a whole is crucial to all the stakeholders who primarily are the developer, the land owner and property buyer. The timely completion of a project that is not only within the budget but also in accordance to specifications and the stakeholder's satisfaction benefits both the project owner (developer) and the property buyer [10]. Every project development will undergo some form of project life cycle (PLC) [11]. In general, Statutory control and approval for development may be divided into four key stages (Abdul Rashid, 2002); Development Order (Stage One), Building and Services plan (Stage Two), Construction (Stage Three) and Certificate of Completion and Compliance (Stage Four).

The construction permit or the building and services plan (building plan) approval come as the most important stage in development as it will determine the exact date for construction to start. Applying for building plan approval as the first step before development begins to ensure that development plans will be reviewed by qualified personnel to limit the risk of construction failures. If the building plan does not need a review from anyone, there will be no clear way to make sure that any developments complied with proper standards or laws.

A person may carry out any building work once he is being granted the formal approval (building plan approval) by the approval giving the party (normally the local council) under the building act (or building code). A building plan approval is therefore needed before any work may commence on any proposed development. A development project; big or small; that involved construction, renovation, addition, removing or clearing an existing building (demolition) is all being considered as construction and development work.

The local government is responsible for ensuring that all application for related construction works follows all the rules and related laws. The records of the related construction works shall be accessible to authorized people; the current or the subsequent owners; and the local government shall be responsible for maintaining the records.

Thus, no building or development can be erected without approval from the local planning authority. To erect a building, the local planning authority may require details related to access, setting backs (or simply called 'setbacks'), elevations, design, site level or any details that they considered necessary for a building. The details shall be shown in a plan and other documents that are prepared by the qualified person that is entitled by law (town planners, architects, engineers, etc.).

To overcome the delay in processing the application, the Ministry of Urban Wellbeing, Housing and Local Government has recommended that a standard, uniform workflow chart be conducted simultaneously by all agencies involved. The Government has agreed with the Strategic Thrust Committee on Government Delivery System chaired by the Chief Secretary to the Government, to set up a local center on two levels; in the local authority and state authority levels to facilitate the building plan approval process and the release of certificates of occupation [12]. With the establishment of this local center; which renamed to One-Stop Centre (OSC); the application process norms can be shortened while improving the delivery system at the local authority level. In this regard, an OSC Committee is established and authorized to consider and decide upon the application for planning permission, building plan and inform planning approvals, simultaneous application of subdivision and change of conditions and surrender and realienation to land administrator [13].

\section{Equations and mathematics}

This study focused on the effectiveness of building plan approval process in Subang Jaya Municipal Council.

\subsection{Case Study}

The Subang Jaya Municipal Council (MPSJ) was established in accordance with the Local Government [14] under Section 4. Previously it was called the Petaling District Council before being known now as the Subang Jaya Municipal Council. The MPSJ is one of the local authorities located within the Klang Valley Region. The area covers 161.8 square kilometres. It consists of two (2) sub-districts namely Damansara and Petaling. MPSJ has a strategic location because it borders the Kuala Lumpur City Hall (DBKL), Shah Alam City Council (MBSA), Petaling Jaya City Council (MBPJ) and the Klang Municipal Council (MPK) (Fig. 1.). 


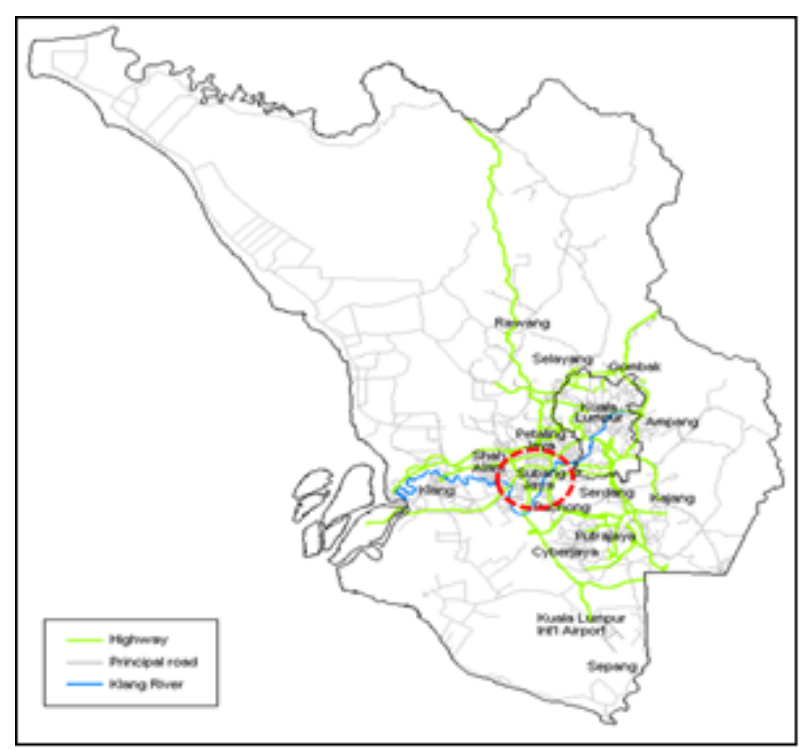

Fig. 1. Study Area

Source: [15]

\subsection{Questionnaire Survey}

The questionnaire is designed to collect information regarding the roles of OSC Department, building plan procedure and its issues in Subang Jaya Municipal Council (MPSJ). A total of 47 respondents were selected from the MPSJ's internal technical departments by using purposive sampling method. 47 sets of questionnaires were distributed to four (4) of MPSJ's internal technical departments which are OSC Department, Building Department, Town Planning Department and Engineering Department. From the 47 set of questionnaires, seven (7) sets were distributed to the OSC Department, eight (8) sets were distributed to the Engineering Department, ten (10) sets were distributed to the Building Department and twenty-two (22) sets distributed to the Town Planning Department.

For most of the questions, respondents are to respond to the statements in the questionnaire based on the five-point scale to indicate their agreement or disagreement by ticking (/) appropriately on the scale provided. The five-point scale varying from Strongly Disagree (1), Disagree (2), Neutral (3), Agree (4) and Strongly Agree (5).

\subsection{Method of Analysis}

The data were analysed using the Statistical Package for Social Science (SPSS) software. The purpose of the analysis is to find out the effectiveness of building plan approval process in Subang Jaya Municipal Council.

\section{Results and discussion}

For the analysis of effectiveness, the respondents' satisfaction on the issues in building plan approval was discussed. Then followed by the role of OSC in the local authority. Lastly, the discussion was focused on the OSC procedure and time frame.

\subsection{Issues in building plan approval}

The questions in require officers of the technical department to reflect on issues related to the application for approval of development plans at MPSJ among others pertaining to the management of applications at the MPSJ, OSC Committee Meetings, legal requirements and difficulties during the application.

Some of the respondent agrees that the officers in MPSJ were constantly being reshuffled $(29.79 \%, 14$ respondent) while only nine respondents $(19.15 \%)$ disagree. Most of the respondents (51.06\%, 24 respondents) unsure whether the reshuffling was constantly being done. Most respondent (51.06\%, 24 respondents) agree that most PSP lacked the knowledge for the job. However, most of the respondents felt that MPSJ has a strict building plan procedures $(44.68 \%, 21$ respondents) and the procedures involved too many officers (65.96\%, 31 respondents).

The letters sent to MPSJ are being managed by hierarchical order $(74.47 \%, 35$ respondents) and the officers in charge normally received the letter, not the same day it was received and this promotes delay. The PSP; due to lack of knowledge; have often presented MPSJ with incomplete documents during discussion and pre-consultation $(59.57 \%, 28$ respondents) thus causing the delay in the process. However, MPSJ felt that the requirements of building plan $(51.06 \%, 24$ respondents) and the statutory clock $(51.06 \%, 24$ respondents $)$ have been fully understood by all related parties. 33 respondents $(70.21 \%)$ have stated that they would like to have an online notification system adopted by MPSJ as this will combat the delay caused by post mails.

Table 1. Issues in building plan approval

\begin{tabular}{|c|l|l|l|l|l|l|}
\hline $\begin{array}{l}\text { Issues in building plan } \\
\text { approval }\end{array}$ & $\mathbf{1}$ & $\mathbf{2}$ & $\mathbf{3}$ & $\mathbf{4}$ & $\mathbf{5}$ \\
\hline 1 & $\begin{array}{l}\text { The local authority has } \\
\text { inadequate officers }\end{array}$ & 5 & 10 & 17 & 11 & 4 \\
\hline 2 & $\begin{array}{l}\text { Officers of local authority } \\
\text { unclear of OSC } \\
\text { procedures }\end{array}$ & 3 & 22 & 13 & 8 & 1 \\
\hline 3 & $\begin{array}{l}\text { Constant reshuffling of } \\
\text { officers in local authority }\end{array}$ & 3 & 6 & 24 & 12 & 2 \\
\hline 4 & $\begin{array}{l}\text { Building plan applicant } \\
\text { lack of knowledge on the } \\
\text { job tasks }\end{array}$ & - & 6 & 17 & 20 & 4 \\
\hline 5 & $\begin{array}{l}\text { Strict regulations for } \\
\text { building plan } \\
\text { procedures/applications }\end{array}$ & 1 & 8 & 17 & 16 & 5 \\
\hline 6 & $\begin{array}{l}\text { Involve too many officers } \\
\text { in the department }\end{array}$ & - & 6 & 10 & 27 & 4 \\
\hline 7 & $\begin{array}{l}\text { Lack of transparency in } \\
\text { pre-consultation, fee } \\
\text { calculation, plan } \\
\text { requirement etc }\end{array}$ & 5 & 15 & 14 & 10 & 3 \\
\hline $\begin{array}{l}\text { a) Letters sent to MPSJ } \\
\text { being managed by } \\
\text { hierarchical order }\end{array}$ & 1 & 3 & 8 & 25 & 10 \\
\hline $\begin{array}{l}\text { building plan } \\
\text { understandable to all } \\
\text { stakeholders }\end{array}$ & - & 11 & 12 & 22 & 2 \\
\hline c) Clear statutory clock & - & 10 & 13 & 21 & 3 \\
\hline
\end{tabular}




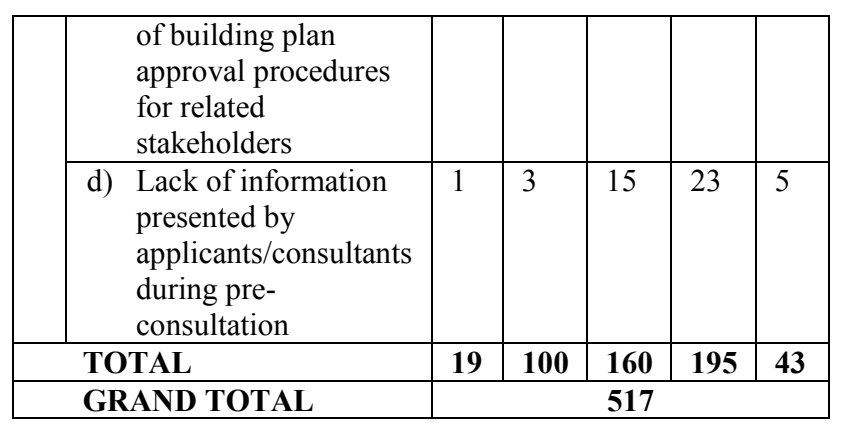

\subsection{Role of OSC in local authority}

The questions require the officers to comment on the roles of OSC Department at MPSJ and its current competency in handling the application for new developments in MPSJ. The questionnaire aims to identify the capability and capacity of OSC Department to fulfill their role in MPSJ.

Most of the respondents are not sure $(46.81 \%, 22$ respondents) whether the public fully understands the current procedures of OSC Department while some does not think the public understand at all $(31.91 \%, 15$ respondents). Only a few believe the public understand the procedures of OSC Department $(21.28 \%, 10$ respondents). The respondents, however, agreed that technical departments within MPSJ do understand the procedures $(42.55 \%, 20$ respondents) while only some are unsure $(34.04 \%, 16$ respondents). Only a few believe the internal technical departments do not understand the procedures $(23.41 \%, 11$ respondents). The respondents feel that manpower in OSC Department of MPSJ is adequate at the moment $(44.68 \%, 21$ respondents) but they believe that they need to add more manpower in the future time (57.45\%, 27 respondents).

Most of the respondents believe that officers of OSC department have the skills $(63.83 \%, \quad 30$ respondents) and the knowledge $(65.96 \%, 31$ respondents) required to manage building plan applications and procedures. However, the respondents believe that OSC officers should possess the ability to instruct PSP much better because 11 respondents $(23.40 \%)$ does not agree that OSC officers were ever capable of doing that while 16 respondents $(34.04 \%)$ unsure whether OSC officers ever able to do that. Only 20 respondents $(42.56 \%)$ believe OSC officers capable of instructing the PSP in the procedure.

Table 2. Role of OSC in the local authority

\begin{tabular}{|c|l|c|c|c|c|c|}
\hline \multicolumn{2}{|l|}{$\begin{array}{l}\text { Role of OSC in the local } \\
\text { authority }\end{array}$} & $\mathbf{1}$ & $\mathbf{2}$ & $\mathbf{3}$ & $\mathbf{4}$ & $\mathbf{5}$ \\
\hline 1 & $\begin{array}{l}\text { The current manpower in } \\
\text { OSC is adequate }\end{array}$ & 2 & 13 & 11 & 14 & 7 \\
\hline 2 & $\begin{array}{l}\text { OSC need further } \\
\text { reinforcement in } \\
\text { manpower }\end{array}$ & 1 & 7 & 12 & 15 & 12 \\
\hline 3 & $\begin{array}{l}\text { Other technical } \\
\text { departments within MPSJ } \\
\text { understand the current } \\
\text { procedures of OSC }\end{array}$ & 2 & 13 & 22 & 9 & 1 \\
\hline 4 & $\begin{array}{l}\text { Officers of OSC have } \\
\text { skills required to manage }\end{array}$ & - & 11 & 16 & 18 & 2 \\
\hline
\end{tabular}

\begin{tabular}{|c|l|c|c|c|c|c|}
\hline & $\begin{array}{l}\text { building plan applications } \\
\text { and procedures }\end{array}$ & & & & & \\
\hline 5 & $\begin{array}{l}\text { Strict regulations for } \\
\text { building plan } \\
\text { procedures/applications }\end{array}$ & - & 3 & 14 & 24 & 6 \\
\hline $\begin{array}{l}\text { a) Reviewing building } \\
\text { plans/ related plans }\end{array}$ & 2 & 6 & 10 & 24 & 5 \\
\hline $\begin{array}{l}\text { b) Linking the } \\
\text { requirements of } \\
\text { departments within MPSJ } \\
\text { (building, engineering } \\
\text { and town planning } \\
\text { department into the plan. }\end{array}$ & 1 & 8 & 11 & 23 & 4 \\
\hline $\begin{array}{l}\text { c) Instruct applicants } \\
\text { (architects, engineer and } \\
\text { town planners) to amend } \\
\text { their plan }\end{array}$ & 1 & 10 & 16 & 17 & 3 \\
\hline $\begin{array}{l}\text { d) Calculate and endorse } \\
\text { amount of monies and } \\
\text { fees related to the } \\
\text { development }\end{array}$ & 1 & 11 & 11 & 21 & 3 \\
\hline 6 & $\begin{array}{l}\text { OSC department officers } \\
\text { possess the knowledge } \\
\text { required to manage } \\
\text { building plan applications } \\
\text { and procedures }\end{array}$ & - & 1 & 15 & 25 & 6 \\
\hline $\begin{array}{l}\text { a) MPSJ Policies and } \\
\text { standing instructions }\end{array}$ & - & 1 & 15 & 26 & 5 \\
\hline $\begin{array}{l}\text { b) Related to Uniform } \\
\text { Building By-Laws } \\
\text { requirements }\end{array}$ & - & 5 & 11 & 28 & 3 \\
\hline $\begin{array}{l}\text { c)Related to Road } \\
\text { Drainage and Building } \\
\text { Act, Act 133 } \\
\text { requirements }\end{array}$ & - & 4 & 11 & 28 & 4 \\
\hline $\begin{array}{l}\text { d)Related to Town and } \\
\text { Country Planning Act, } \\
\text { Act 172 requirements } \\
\text { Authority Act, Act 171 } \\
\text { requirements }\end{array}$ & - & 4 & 9 & 30 & 4 \\
\hline f) OSC Manuals & & & & & \\
\hline $\begin{array}{l}\text { g) MPSJ related work } \\
\text { procedure }\end{array}$ & - & 2 & 10 & 31 & 4 \\
\hline TOTAL & & & & & \\
\hline GRAND TOTAL & & & & & \\
\hline
\end{tabular}

\subsection{OSC procedure and time frame}

This section seeks to answer questions on time stated in OSC Procedure for processing of new building permit application. This section will help identify whether the officers within the internal technical departments are well-aware of the time frame and duration of OSC work procedure.

From the survey, it was found that the OSC Department has done everything necessary to inform all stakeholders about its procedure and the duration related to the procedures $(65.96 \%, 31$ respondents). The survey has also shown that the OSC Department has served purposes that were initially outlined in the year 2007 (63.83\%, 30 respondents). The OSC procedures have helped simplified land related procedures $(55.32 \%, 26$ respondents) and it has helped create the Concurrent 
Development Procedures for Build-Then-Sell and SellThen-Build developments (51.06\%, 24 respondents).

However, the respondents doubt that OSC Department ever had the Fastlane Priority for BuildThen-Sell because 9 respondents (19.14\%) does not agree that it ever existed while 19 respondents (40.43\%) unsure whether OSC Department ever had that Fastlaneprocedure. Only 19 respondents $(40.43 \%)$ believe that was on the cards. Most of the respondents agree that time needed for first checking and review is 14 days (78.72\%, 37 respondents) and all applications will be brought to OSC Committee meeting within 30 days (82.98\%, 39 respondents). After the meeting, the respondents believe that the applicant may return the amended plans within 60 days from the date of release of OSC meeting's minutes $(57.45 \%, 27$ respondents). The respondent also feels that most PSP has been able to give a speedy return of the amended plan on time $(55.32 \%, 26$ respondents).

Table 3. OSC procedure and time frame

\begin{tabular}{|c|c|c|c|c|c|c|}
\hline \multicolumn{2}{|c|}{$\begin{array}{l}\text { OSC procedure and time } \\
\text { frame }\end{array}$} & \multirow{2}{*}{$\begin{array}{l}1 \\
-\end{array}$} & \multirow{2}{*}{$\begin{array}{l}2 \\
1\end{array}$} & \multirow{2}{*}{\begin{tabular}{r|}
3 \\
16
\end{tabular}} & \multirow{2}{*}{$\begin{array}{l}4 \\
28\end{array}$} & \multirow[b]{2}{*}{2} \\
\hline 1 & $\begin{array}{l}\text { OSC serve purposes } \\
\text { initially outlined in the } \\
\text { year } 2007\end{array}$ & & & & & \\
\hline & $\begin{array}{l}\text { a) Fastlane priority for } \\
\text { build-then-sell (BKJ) } \\
\text { project ( } 4 \text { months approval } \\
\text { time) }\end{array}$ & - & 9 & 19 & 17 & 2 \\
\hline & $\begin{array}{l}\text { b) Simplified land related } \\
\text { procedures }\end{array}$ & - & 6 & 15 & 23 & 1 \\
\hline & $\begin{array}{l}\text { c)Two simultaneous } \\
\text { development procedure } \\
\text { (for BKJ and sell-then- } \\
\text { build JKB) }\end{array}$ & - & 5 & 18 & 23 & 1 \\
\hline \multirow[t]{7}{*}{2} & $\begin{array}{l}\text { OSC inform all } \\
\text { stakeholders of the } \\
\text { procedures and duration }\end{array}$ & 1 & 4 & 11 & 29 & 2 \\
\hline & $\begin{array}{l}\text { a) The procedures } \\
\text { accessible at the counter }\end{array}$ & - & 5 & 8 & 31 & 3 \\
\hline & $\begin{array}{l}\text { b) The procedures } \\
\text { accessible via a website }\end{array}$ & - & 1 & 7 & 32 & 7 \\
\hline & $\begin{array}{l}\text { c)The procedures } \\
\text { accessible via publication }\end{array}$ & - & 5 & 16 & 24 & 2 \\
\hline & $\begin{array}{l}\text { d)Information/documents } \\
\text { required for every } \\
\text { application }\end{array}$ & - & - & 7 & 37 & 3 \\
\hline & $\begin{array}{l}\text { e) The expected time or } \\
\text { duration involved with the } \\
\text { procedure }\end{array}$ & - & 1 & 12 & 25 & 6 \\
\hline & $\begin{array}{l}\text { f) In-depth pre- } \\
\text { consultation }\end{array}$ & 1 & 3 & 12 & 25 & 6 \\
\hline 3 & $\begin{array}{l}\text { The needs for first } \\
\text { checking and review is } 14 \\
\text { days }\end{array}$ & - & 2 & 8 & 30 & 7 \\
\hline 4 & $\begin{array}{l}\text { Applications will be } \\
\text { brought to OSC committee } \\
\text { meeting within } 30 \text { days }\end{array}$ & - & 2 & 6 & 30 & 9 \\
\hline 5 & $\begin{array}{l}\text { Applicant return the } \\
\text { amended plans within } 60 \\
\text { days from the date of } \\
\text { release minutes of OSC } \\
\text { meeting }\end{array}$ & 1 & 7 & 12 & 23 & 4 \\
\hline 6 & Speedy return of amended & - & 6 & 15 & 24 & 2 \\
\hline
\end{tabular}

\begin{tabular}{|l|l|l|l|l|l|l|}
\hline plan from the applicant & & & & & \\
\hline TOTAL & $\mathbf{3}$ & $\mathbf{5 7}$ & $\mathbf{1 8 2}$ & $\mathbf{4 0 7}$ & $\mathbf{5}$ \\
& & \multicolumn{5}{|c|}{$\mathbf{7 0 5}$} \\
\hline GRAND TOTAL & \multicolumn{5}{|c|}{} \\
\hline
\end{tabular}

\section{Conclusion}

One of the issues in building plan application is the delays. Sometimes, the delays are caused by the OSC Procedure itself. Sometimes the Professional Submitting Person (PSP) presented MPSJ with inadequate documents that end up dragging the application further into the delay. The delay is also caused by the OSC Department counter because the counter is running short of manpower and expertise.

For OSC Department to have a defined role, OSC must be the centre for excellence (for development approving) where both the department and its personnel must be highly competent and well-versed with all related development matters. Pre-consultation is crucial as stated by the World Bank in its publications. The OSC Department must be able to answer questions asked by the applicants. To be able to do that, the OSC Department must involve more with the development matters as this will surely promote transparency not just within the OSC Department but also in the local authority itself.

The authors would like to thank Universiti Teknologi MARA (UiTM) for the support and partly funding the study and publication through the LESTARI research grant (600IRMI/MYRA 5/3/LESTARI (K) (237/2017)). The authors are also thankful to all the departments, organisations, and individual who had contributed to this study.

\section{References}

1. United Nations. The World Cities in 2016 Data Booklet, 2016 [Online]. Available: www.un.org/en/.../desa/population/.../the_worlds_c ities_in_2016_data_booklet.pdf [Accessed,2016].

2. Global Construction 2025 Report, 2013. [Online] Available: https://assets.publishing.service.gov.uk

3. United Nations, 2017. Sustainable Development Goals.[Online] Available: http://www.un.org/sustainabledevelopment/sustaina ble-development-goals/

4. Moullier, T. Reforming Building Permits: Why is It Important and What Can IFC Really Do? International Finance Corporation, Washington, DC. (2009).

5. Hernando, D.S. The Mystery of Capital: Why Capitalism Triumphs in the West and Fails Everywhere Else. Basic Books, New York. (2000)

6. Laws of Malaysia. Street, Drainage and Building Act (Act 133). Kuala Lumpur: International Law Books Services.

7. Kincaid D. Adapting buildings for changing uses, guidelines for change of use refurbishment. Spon Press: London. (2003). 
8. Mitropoulos, \& Howell. Renovation projects: Design process problems and improvement mechanisms. Journal of Management in Engineering, 18 (4): 179-185. (2002).

9. McKim, R. Tarek, H. \& Attalla, M. (2000). Project Performance Control in Reconstruction Project. Journal of Construction Engineering and Management 126 (2): 137-14. (2000).

10. Nguyen, L.D., Ogunlana, S.O. \& Lan, D.T.X. $A$ Study On Project Success Factors In Large Construction Projects In Vietnam. Engineering, Construction and Architectural Management, 11 (6): 404-413. (2004).

11. Kerzner, H. Project Management: A System Approach to Planning, Scheduling, and Controlling (10th ed.). Van Nostrand, New York. (2009).

12. Fadzil, M. Penambahbaikan Sistem Penyampaian Prosedur Dan Proses Serta Pelaksanaan Pusat Setempat Bagi Cadangan Pemajuan. Town and Country Planning Department of Malaysia. Kuala Lumpur. (2007)

13. Ministry of Housing and Local Government, Malaysia Upgrading of the Procedure on the Delivery System and Development Plan Process and the Implementation of the One Stop Centre (2nd ed.). Kuala Lumpur: Malaysia. (2008).

14. Laws of Malaysia. Local Government Act 1976 (Act 171). Kuala Lumpur: International Law Books Services

15. Subang Jaya Municipal Council, 2015. [Online]. Available http://ocps.mpsj.gov.my). 